\title{
Reported incidence of occupational asthma in the United Kingdom, 1989-90
}

\author{
Sarah Meredith
}

\begin{abstract}
Study objective-To estimate the incidence of occupational asthma seen by respiratory and occupational physicians in the UK in 1989 and 1990.

Design-New cases of occupational asthma were taken from a national reporting scheme, the Surveillance of Work-related and Occupational Respiratory Disease Project (SWORD). Estimates of the working population from the Labour Force Survey were used to calculate reported incidence by age group, sex, occupation, and region.

Setting-The SWORD project is a scheme for the reporting of new cases of work-related respiratory disease by thoracic and occupational physicians from throughout the UK which began in 1989 .
\end{abstract}

Patients-In 1989 and 1990 , of 4229 cases reported, $1085(26 \%)$ were in patients with occupational asthma.

Main results-Only half the reported cases were attributed to agents prescribed under the Industrial Injuries Scheme. There was considerable diversity in risk by occupation, with highest annual rates in welders, solderers, and electronic assemblers (175/ million), laboratory workers (188/million), metal treaters (267/millon), bakers (334/ million), plastics workers (337/million), chemical processors $(364 /$ million), and spray painters $(658 /$ million). Crude rates in men were higher than in women, but rates within occupations were similar in both sexes. Rates of disease rose with age; adjustment for occupation increased the gradient. Regional differences were only partly explained by diversity of industry and were probably mainly due to variation in levels of ascertainment and reporting.

Conclusions-Asthma is the most commonly reported occupational lung disease in the UK. The incidence in the general population is unknown, but it was estimated that the incidence of new cases seen by respiratory and occupational physicians was about three times that reported. High relative risks were found in a number of occupations in which effective control of the work environment is urgently required.

F Epidemiol Community Health 1993; 47: 459-463

Occupational asthma is important because it is a preventable cause of serious long term disability, but the number of people affected is not known. Statistics based on disablement benefit awards underestimate the disease frequency and until very recently only cases attributed to certain agents were recognised for an award. ${ }^{1}$ This report is an analysis of new cases of occupational asthma from throughout the United Kingdom notified in 1989 and 1990 to a confidential and voluntary scheme, the Surveillance of Work-related and Occupational Respiratory Disease project (SWORD). The analysis aimed to estimate the risk of reported disease by occupation, sex, age group, and region in the UK.

\section{Methods}

The SWORD project, its background, and methods have been described previously. ${ }^{2}$ Briefly, new cases of work related respiratory disease seen by participating chest and occupational physicians from throughout the $\mathrm{UK}$ are reported on a regular basis. In 1989 and 1990, the first two years of the project, there were over 700 participating physicians equally divided between the two specialities. Chest physicians represented $83 \%$ of consultants listed in the handbook Thoracic Medical Services in the United Kingdom, ${ }^{3}$ and included at least one physician in $90 \%$ of the country's chest clinics. Contributing and non-contributing clinics were fairly evenly distributed apart from a few areas of relatively poor participation, mainly in the south and east. The cases were newly diagnosed and were reported by most chest physicians in the UK, and so considered against estimates of the population at risk, rates for particular groups could be calculated.

Altogether 4229 cases of work related respiratory disease were reported in the first two years of the project, $1118(26 \%)$ of which were of occupational asthma. After removal of $33(3 \%)$ duplicates, 1085 cases remained -540 reported in 1989 and 545 in $1990 ; 824(76 \%)$ were reported by chest physicians. Occupation was coded according to the Office of Population Censuses and Surveys (OPCS) 1980 classification, ${ }^{4}$ and the place of residence according to the standard administrative regions. In 62 cases $(5 \cdot 7 \%)$ no place of residence was specified; these were allocated to the region in which the reporting physician worked.

The 404 occupation groups of the 1980 OPCS classification were aggregated in two ways (table I). The first was the standard grouping which combines occupations into 16 "orders"; the second, referred to as "occupational sets" we developed to study occupational rates in more detail while minimising misclassification. An occupational set covered all possible codes for the same occupation. For instance, someone described as a laboratory worker might be a 
Table I Occupational classifications

\begin{tabular}{|c|c|c|c|}
\hline \multicolumn{2}{|c|}{ Ordert } & \multirow{2}{*}{$\begin{array}{l}S_{e t} \\
\text { Remainder professional, clerical, \& service }\end{array}$} & \multirow{3}{*}{$\begin{array}{l}\text { Group codt } \\
19\end{array}$} \\
\hline (1) & Professional \& related supporting management & & \\
\hline & $\begin{array}{l}\text { Professional \& related in education, welfare \& health } \\
\text { Nurses }\end{array}$ & Nurses & \\
\hline & Remainder & Remainder professional, clerical, \& service & $10-15,17-18$ \\
\hline (3) & Literary, artistic \& sports & Remainder professional, clerical, \& service & $19-23$ \\
\hline \multirow[t]{3}{*}{ (4) } & Professional \& related in science, engineering, \& technology & & \\
\hline & Laboratory technicians & in Laboratory technicians \& assistants & $30 \cdot 1$ \\
\hline & Remainder & Remainder professional, clerical, \& service & $24-29,30 \cdot 233$ \\
\hline \multirow{3}{*}{$(5)$} & Managerial & & \\
\hline & Farmers, horticulturalists \& farm managers & in Farmers \& farm workers & 40 \\
\hline & $\begin{array}{l}\text { Remainder } \\
\text { Clerical \& related }\end{array}$ & Remainder professional, clerical \& service & $34-39,41-44$ \\
\hline \multirow{6}{*}{$\begin{array}{l}(6) \\
(7) \\
(8) \\
(9)\end{array}$} & Selling & Remainder professional, clerical \& service & $45-62$ \\
\hline & Security \& protective services & 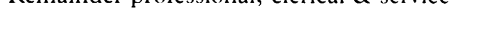 & 80 \\
\hline & Catering, cleaning, hairdressing \& other personal services & & \\
\hline & Hairdressers & Hairdressers & 73,74 \\
\hline & Cleaners & Cleaners & $71 \cdot 1-71 \cdot 2,72 \cdot 1 \quad 72 \cdot 2$ \\
\hline & Remainder & Remainder professional, clerical \& service & $63-75$ excluding the above \\
\hline \multirow[t]{3}{*}{$(10)$} & Farming, fishing, \& related & & \\
\hline & Farm and horticultural workers & in Farmers \& farm workers & $76 \cdot 1-76 \cdot 2,77 \quad 78 \cdot 1$ \\
\hline & Remainder & Remainder professional, clerical \& service & $76-83$ excluding the above \\
\hline \multirow[t]{7}{*}{ (11) } & Materials processing, making, \& repairing (excluding metal $\&$ & rical) & \\
\hline & Chemical processors & Chemical processors & 8889 \\
\hline & Bakers & Bakers & $90 \cdot 1,90 \cdot 5,91,98 \cdot 5$ \\
\hline & Other food processors & Other food processors & $90 \cdot 2-3,90 \cdot 6,92 \cdot 12,98 \cdot 7$ \\
\hline & Plastics workers & Plastics workers & $95 \cdot 5,95 \cdot 10,97 \cdot 2,107 \cdot 11$ \\
\hline & Wood workers & Wood workers & $104107 \cdot 1,107 \cdot 6$ \\
\hline & Remainder & Remainder non-metal/electrical processors & 84107 excluding the above \\
\hline \multirow[t]{4}{*}{ (12) } & Processing, making, repairing \& related (metal \& electrical) & & \\
\hline & Metal making \& treating & Metal making \& treating & $108110,131 \cdot 2 \quad 131 \cdot 3$ \\
\hline & Welders & Welders, solderers \& electronic assemblers & $124 \cdot 6,128$ \\
\hline & Remainder & Remainder metal \& electrical processors & 104-131 excluding the above \\
\hline \multirow[t]{13}{*}{ (13) } & Painting, repetitive assembling etc & & \\
\hline & Coach \& other spray painters & Spray painters & $132 \cdot 2-3,133 \cdot 23$ \\
\hline & Other painters & Other painters & $132 \cdot 4,133 \cdot 4$ \\
\hline & Electronics assemblers & in Welders, solderers \& electronic assemblers & $134 \cdot 1,135 \cdot 1$ \\
\hline & Laboratory assistants & in Laboratory technicians \& assistants & $136 \cdot 8,138 \cdot 1$ \\
\hline & Remainder & Remainder painting, assembly \& packaging & 132-138 excluding the above \\
\hline & Construction, mining \& related & Construction \& mining & 139146 \\
\hline & Transport operating, materials moving \& storing & Transport \& storage & $147-158$ \\
\hline & $\begin{array}{l}\text { Miscellaneous labourers \& unskilled workers } \\
\text { Textiles, glass, ceramics \& others }\end{array}$ & in Remainder non-metal electrical processors & $159 \cdot 1,159 \cdot 4,159 \cdot 8,160 \cdot 1,160 \cdot 4,160 \cdot 8$ \\
\hline & Chemicals, coke and gas works & in Chemical workers & $159 \cdot 2-3,160 \cdot 23$ \\
\hline & Foundries & in Metal making \& treating & $159 \cdot 5,160 \cdot 5$ \\
\hline & Engineering and allied trades $\&$ boiler operators & in Remainder metal \& electrical processors & $159 \cdot 6,159 \cdot 9,160 \cdot 6,161 \cdot 1$ \\
\hline & Mining & in Construction \& mining & $159 \cdot 7,160 \cdot 7$ \\
\hline
\end{tabular}

technician, a laboratory assistant, or a foreman laboratory assistant, each of which has a different code; the three were therefore combined as a single occupational set.

Incidence rates were based on estimates of the working population derived from the 1989 and 1990 OPCS Labour Force Surveys (LFS) by region, sex, age group, and occupation (unpublished data). Most analyses were confined to the 995 cases $(92 \%)$ in which age, sex, and occupation were specified by the reporting physician. All rates are expressed per million working persons per year.

Expected numbers in each sex and age group after adjustment for occupation were calculated by indirect standardisation using the crude rates by occupational order. A standardised rate ratio was then calculated, and rates by sex and age group adjusted for occupation were derived by multiplying the crude rate by the standardised rate ratio.

It was thought that regional variation in rates was probably the result of differences in ascertainment and reporting as well as differences in the distribution of the working population. To explore this, expected numbers in each region were calculated by indirect standardisation for sex, age group, and occupational order. Standardised rates were not estimated in the geographical analyses as these would simply have magnified the observed regional variation.

\section{Results}

SUSPECTED AGENTS

The suspected causal agents are shown in table II. For half the cases the suspected agent was one of the 14 officially prescribed at that time $;^{5}$ " the nine additional agents recommended in October 1990 for prescription ${ }^{7}$ accounted for a further 59 cases $(5.4 \%)$, in $9 \%$ the cause was unknown or not specified, leaving 381 cases (35\%) attributed to a wide variety of other agents. Some of these, such as the paints and glues, should perhaps have been classified with prescribed agents, but could not be because of inadequate information; others were clearly not included. Of note were the 52 cases attributed to organic materials such as spices (six cases), poultry (five cases), cotton (four cases), and wool ( 3 cases). Cases attributed to metals other than stainless steel welding fume formed another important group, in particular those associated with aluminium potroom emissions (16 cases).

Isocyanates were the most commonly suspected cause of occupational asthma and were implicated in many occupational sets. Of the 241 patients, 68 $(28 \%)$ were painters, $40(17 \%)$ plastic manufacturers, $11(5 \%)$ chemical processors, and 81 $(34 \%)$ were in other manufacturing occupations.

OCCUPATION, SEX, AND AGE

The crude annual incidence of occupational asthma reported to SWORD was 20 per million working populated $(/ \mathrm{mil})$. Three of the 16 occupational orders, which contain most of the manufacturing occupations and included $72 \%$ of cases, had the highest rates of disease: order $11-$ materials processing, making, and repairing (excluding metal and electrical), 319 cases (95/mil); Order 12-metal and electrical processing, making, and repairing, 217 cases (44/mil); and order 13-painting, assembly, and packaging, 181 cases $(95 / \mathrm{mil})$. 
Table II Cases in relation to the agent suspected of causing their asthma

\begin{tabular}{|c|c|c|}
\hline Agents & Cases & $(\%)$ \\
\hline $\begin{array}{l}\text { Prescribed agents } \\
\text { Isocyanates } \\
\text { Platinum salts } \\
\text { Hardening agents } \\
\text { Soldering flux } \\
\text { Proteolytic enzymes } \\
\text { Laboratory animals insects } \\
\text { Flour grain } \\
\text { Antibiotics } \\
\text { Wood dusts } \\
\text { Azodicarbonamide }\end{array}$ & $\begin{array}{r}241 \\
7 \\
20 \\
69 \\
5 \\
49 \\
81 \\
15 \\
47 \\
10\end{array}$ & $\begin{array}{l}(22 \cdot 2) \\
(0 \cdot 6) \\
(1 \cdot 8) \\
(6 \cdot 4) \\
(0 \cdot 5) \\
(4 \cdot 5) \\
(7 \cdot 5) \\
(1 \cdot 4) \\
(4 \cdot 3) \\
(0 \cdot 9)\end{array}$ \\
\hline $\begin{array}{l}\text { Agents not prescribed } \\
\text { Organic: } \\
\text { Soya beant } \\
\text { Green coffec beant } \\
\text { Other plant matter fungi } \\
\text { Crustaceans and fish } \dagger \\
\text { Other animal antigens } \\
\text { Other organic origin not specified }\end{array}$ & $\begin{array}{r}2 \\
1 \\
31 \\
19 \\
18 \\
3\end{array}$ & $\begin{array}{l}(0 \cdot 2) \\
(0 \cdot 1) \\
(2 \cdot 9) \\
(1 \cdot 8) \\
(1 \cdot 7) \\
(0 \cdot 3)\end{array}$ \\
\hline $\begin{array}{l}\text { Chemical: } \\
\text { Glutaraldehydet } \\
\text { Formaldehyde } \\
\text { Ethylene diamine } \\
\text { Chlorine } \\
\text { Ammonia } \\
\text { Styrene } \\
\text { Other chemicals }\end{array}$ & $\begin{array}{r}20 \\
12 \\
7 \\
6 \\
5 \\
4 \\
55\end{array}$ & $\begin{array}{l}(1 \cdot 8) \\
(1 \cdot 1) \\
(0.6) \\
(0.6) \\
(0.5) \\
(0.4) \\
(5 \cdot 1)\end{array}$ \\
\hline $\begin{array}{l}\text { Metal: } \\
\text { Stainless steel welding fumet } \\
\text { Other welding fume } \\
\text { Aluminium potroom emissions } \\
\text { Cobalt } \\
\text { Chrome } \\
\text { Nickel } \\
\text { Other metals }\end{array}$ & $\begin{array}{r}3 \\
20 \\
16 \\
8 \\
8 \\
4 \\
6\end{array}$ & $\begin{array}{l}(0 \cdot 3) \\
(1 \cdot 8) \\
(1 \cdot 5) \\
(0.7) \\
(0.7) \\
(0 \cdot 4) \\
(0.6)\end{array}$ \\
\hline $\begin{array}{l}\text { Miscellaneous: } \\
\text { Other glues and resins } \\
\text { Paints } \\
\text { Cutting oils } \\
\text { Cleaning products \& disinfectants } \\
\text { Persulphate salts and hennat } \\
\text { Other hair products } \\
\text { Reactive dyest } \\
\text { Other inks and dyes } \\
\text { Insecticides \& fungicides } \\
\text { Dust unspecified } \\
\text { Other specified agents } \\
\text { Agent not specified or unknown } \\
\text { Total }\end{array}$ & $\begin{array}{r}34 \\
23 \\
18 \\
17 \\
7 \\
7 \\
7 \\
7 \\
7 \\
8 \\
57 \\
101 \\
1085\end{array}$ & $\begin{array}{c}(3 \cdot 1) \\
(2 \cdot 1) \\
(1.7) \\
(1 \cdot 6) \\
(0.6) \\
(0.6) \\
(0 \cdot 6) \\
(0.6) \\
(0.6) \\
(0.7) \\
(5 \cdot 3) \\
(9 \cdot 3) \\
(100)\end{array}$ \\
\hline
\end{tabular}

The crude incidence of occupational asthma in men $(24 / \mathrm{mil})$ was nearly twice that in women $(13 / \mathrm{mil})$. In both sexes the rate seemed to increase with age (table III). A similar trend was also apparent within occupational orders (data not tabulated here). The rates standardised for occupational order rose more steeply with age than the crude rates (table III) because young people of both sexes tended to work in jobs with higher rates of occupational asthma than those in older age groups.

Annual incidence rates by occupational set and sex (table IV) ranged from $3 /$ mil for all those in orders one to 10 (excluding cleaners, hairdressers, farmers, and laboratory technicians) to $658 / \mathrm{mil}$ for coach and other spray painters, with little difference between men and women in the same occupational set. Therefore, the sex differences in crude rates were largely explained by differences in the distribution of occupations between men and women.

Table III Incidence rates of occupational asthma in relation to sex and age group * crude and standardised for occupational order

\begin{tabular}{llllllll}
\hline Sex & $\begin{array}{l}\text { Age group } \\
(1)\end{array}$ & $\begin{array}{l}\text { Observed } \\
\text { cases }\end{array}$ & $\begin{array}{l}\text { Observed } \\
\text { rate/mily }\end{array}$ & $(95 \%$ CI) & $\begin{array}{l}\text { Expected } \\
\text { cases }\end{array}$ & $\begin{array}{l}\text { Standardised } \\
\text { rate ratio }\end{array}$ & $\begin{array}{l}\text { Standardised } \\
\text { rate/mily }\end{array}$ \\
\hline Female & $16-29$ & 84 & 11 & $(9,13)$ & $104 \cdot 82$ & $0 \cdot 80$ & 9 \\
& $30-44$ & 98 & 12 & $(10,15)$ & $97 \cdot 50$ & $1 \cdot 01$ & 12 \\
& $\geq 45$ & 104 & 15 & $(12,18)$ & $83 \cdot 68$ & $1 \cdot 24$ & 19 \\
\multirow{4}{*}{ Male } & All & $286^{\star}$ & 13 & $(11,14)$ & & & \\
& $16-29$ & 167 & 17 & $(15,20)$ & $262 \cdot 00$ & $0 \cdot 64$ & 11 \\
& $30-44$ & 249 & 23 & $(21,26)$ & $236 \cdot 97$ & $1 \cdot 05$ & 24 \\
& $\geq 45$ & 293 & 31 & $(27,34)$ & $210 \cdot 03$ & $1 \cdot 40$ & 43 \\
& All & $709^{\star}$ & 24 & $(22,25)$ & & & \\
\hline
\end{tabular}

* Age and sex unknown in 90 cases
REGIONAL DIFFERENCES

Considerable geographical variation in incidence was apparent (table V), from 9/mil (95\% CI 5, $14 / \mathrm{mil}$ ) in West Yorkshire to $65 / \mathrm{mil}$ (95\% CI 55, $76 / \mathrm{mil})$ in the West Midlands Metropolitan County. Rates for Yorkshire and Humberside, the East Midlands, and the South East fell well below the national average of $20 / \mathrm{mil}$, and those for the West Midlands, the North, and Scotland were clearly higher than elsewhere. The standardised rate ratios, which took age, sex, and occupation into account, were raised in the regions with high crude rates, and low in those with low rates, although the variability of the standardised rate ratios was less than that of the crude rates. Thus, the diversity in regional rates was only partially explained by differences in population distribution, which suggests that much of it was probably due to different levels of case ascertainment and reporting.

An intensive surveillance scheme for occupational asthma in the West Midlands Metropolitan County by Gannon and Burge ${ }^{8}$ undoubtedly encouraged a high level of reporting to SWORD in that region. To provide an estimate based on a comparable level of ascertainment from other regions, rates by occupational order in the West Midlands Metropolitan County from SWORD were applied to the UK population. The estimated total number of cases was $2903(55 / \mathrm{mil}), 2 \cdot 7$ times the number reported to the SWORD project in the same period.

\section{Discussion}

Once acquired, occupational asthma may cause respiratory illness for years to come, even after removal from the exposure that caused it. ${ }^{11}$ Prevention therefore depends on the earliest possible identification of occupations at risk and of causal agents, and in the effective control of the work environment.

The number of people with occupational asthma awarded disablement benefit in 1989 and 1990 under the Industrial Injuries Scheme ${ }^{1}$ was slightly lower than the number of cases attributed to prescribed agents reported to SWORD in the same period. Although any resemblance of the figures is to some extent coincidental because they are unlikely to include the same people, the distribution of cases by cause was broadly similar, apart from a larger number attributed to isocyanates and laboratory animals in SWORD. More importantly, the agents officially prescribed in 1989 and 1990 accounted for only half the cases in the present analysis. The legislative change which now permits occupational asthma from other causes to be compensated ${ }^{7}$ is recognition of the much wider list of respiratory sensitisers, but the additional agents now specified cover only a further $5 \%$ of SWORD cases.

No systematic steps were taken to validate the diagnoses of occupational asthma. However, as these were made by specialists in respiratory or occupational medicine they are likely to have been reasonably reliable. Useful evidence on the question was obtained from a study of reported cases of asthma in workers in the chemical and plastics industry. ${ }^{12}$ Of 95 cases studied, 85 had respiratory symptoms which improved on days away from 
Table IV Incidence of occupational asthma in relation to occupational set and sex

\begin{tabular}{|c|c|c|c|c|c|c|c|}
\hline \multirow[b]{2}{*}{ Order } & \multirow[b]{2}{*}{ Occupational set } & \multicolumn{2}{|c|}{ Women } & \multicolumn{2}{|l|}{ Men } & \multicolumn{2}{|c|}{ Sexes combined } \\
\hline & & Cases & $\begin{array}{l}\text { Rate } \\
\text { (mily) }\end{array}$ & Cases & $\begin{array}{l}\text { Rate } \\
(\mathrm{mil} / \mathrm{y})\end{array}$ & $\begin{array}{l}\text { Rate } \\
(\mathrm{mil} / \mathrm{y})\end{array}$ & $(95 \% C I)$ \\
\hline $1-10$ & $\begin{array}{l}\text { Professional, clerical, \& service work } \\
\text { Laboratory technicians \& assistants } \\
\text { Cleaners } \\
\text { Nurses } \\
\text { Farmers and farm workers } \\
\text { Hairdressers } \\
\text { Remainder }\end{array}$ & $\begin{array}{r}25 \\
10 \\
22 \\
7 \\
16 \\
45\end{array}$ & $\begin{array}{r}203 \\
9 \\
17 \\
43 \\
87 \\
3\end{array}$ & $\begin{array}{r}25 \\
5 \\
0 \\
16 \\
0 \\
52\end{array}$ & $\begin{array}{r}174 \\
13 \\
0 \\
24 \\
0 \\
3\end{array}$ & $\begin{array}{r}188 \\
10 \\
16 \\
28 \\
81 \\
3\end{array}$ & $\begin{array}{c}(139,247) \\
(5,16) \\
(10,24) \\
(18,41) \\
(46,131) \\
(2,4)\end{array}$ \\
\hline 11 & $\begin{array}{l}\text { Material processors (excluding metal } \\
\text { Wood workers } \\
\text { Food processors (excluding bakers) } \\
\text { Bakers } \\
\text { Plastics workers } \\
\text { Chemical processors } \\
\text { Remainder }\end{array}$ & $\begin{array}{l}\text { electric } \\
1 \\
15 \\
22 \\
5 \\
5 \\
31\end{array}$ & $\begin{array}{r}35 \\
146 \\
364 \\
163 \\
271 \\
41\end{array}$ & $\begin{array}{l}50 \\
20 \\
28 \\
42 \\
49 \\
63\end{array}$ & $\begin{array}{r}54 \\
90 \\
314 \\
386 \\
377 \\
53\end{array}$ & $\begin{array}{r}54 \\
108 \\
334 \\
337 \\
364 \\
49\end{array}$ & $\begin{array}{c}(40,70) \\
(75,150) \\
(248,440) \\
(248,448) \\
(274,475) \\
(39,60)\end{array}$ \\
\hline 12 & $\begin{array}{l}\text { Metal \& electrical processing and mak } \\
\text { Welding, soldering \& electronic } \\
\text { assembly } \\
\text { Metal treatment } \\
\text { Remainder }\end{array}$ & $\begin{array}{r}44 \\
2 \\
10\end{array}$ & $\begin{array}{r}268 \\
174 \\
48\end{array}$ & $\begin{array}{r}34 \\
41 \\
122\end{array}$ & $\begin{array}{r}120 \\
275 \\
28\end{array}$ & $\begin{array}{r}175 \\
267 \\
29\end{array}$ & $\begin{array}{c}(138,218) \\
(194,360) \\
(24,35)\end{array}$ \\
\hline 13 & $\begin{array}{l}\text { Painting, assembly and packing } \\
\text { Painters (excluding spray painters) } \\
\text { Coach and other spray painters } \\
\text { Remainder }\end{array}$ & $\begin{array}{r}4 \\
1 \\
18\end{array}$ & $\begin{array}{r}510 \\
450 \\
31\end{array}$ & $\begin{array}{l}24 \\
64 \\
23\end{array}$ & $\begin{array}{r}58 \\
663 \\
41\end{array}$ & $\begin{array}{r}66 \\
658 \\
36\end{array}$ & $\begin{array}{c}(44,95) \\
(508,839) \\
(26,49)\end{array}$ \\
\hline 14 & Construction \& mining & 1 & 64 & 21 & 11 & 11 & $(7,17)$ \\
\hline 15 & Transport and storage & 0 & 0 & 23 & 8 & 8 & $(5,11)$ \\
\hline
\end{tabular}

work, 45 had serial respiratory function tests, and in 11 bronchial challenge or specific IgE tests had been performed. In only two cases was there no corroboration of the diagnosis, in one of which the patient had left his job before any investigations could be undertaken. As this case series was selected only on industry these results may well be typical.

Correct identification of the causal agent may have been less reliable, however, as few chest physicians are able to investigate the work environment, and facilities for challenge tests are limited. There may, therefore, have been a tendency to blame agents known to cause asthma rather than other exposures in the work place.

The rates in this analysis provide the only measure of the relative frequency of work related asthma by occupation in the UK so far available. To our knowledge the only other national estimates of the risk of asthma by occupation are from Finland. ${ }^{13}$ Although it is possible that in certain occupations work related asthma has a greater chance of being recognised, and so reported to SWORD, any such bias would only tend to underestimate the incidence in occupations in which the risk was less widely known. Despite underestimation, reporting schemes such as SWORD can draw attention to agents and occupations insufficiently recognised as a source of disease.

Some of the highest rates were in occupational sets well known to be associated with asthma such as laboratory animal workers, ${ }^{14}{ }^{15}$ solderers, ${ }^{16}$ bakers, ${ }^{17}$ chemical processors, plastics workers, ${ }^{18}$ and spray painters. ${ }^{19}$ The latter had a relative risk of occupational asthma that was over 30 times that of the general population; clearly preventive measures for this group are a matter of urgency. High rates were also found in more unexpected occupations such as food processors (other than bakers) and metal treatment workers. Most cases in the latter set were attributed to various metals, in particular aluminium potroom fume. Although a subject of controversy, aluminium smelting has been associated previously with asthma ${ }^{20} 21$ as has foundry work. ${ }^{22}$ However, the relative importance of metal treatment was surprising; although based on fairly small numbers, the set had the fifth highest risk.

The increasing incidence with age, made even greater by standardisation for occupation, was an unexpected finding. Part of the explanation may be patient selection: (i) patients may be more likely to be referred to a chest physician if they develop symptoms later on in life or if they have been ill for some time, and (ii) older employees may wish, despite symptoms, to stay in jobs where they have security and experience and so seek medical help only at a late stage, whereas younger people simply change jobs. On the other hand, susceptibility may increase with age, possibly because of previous occupational exposures or personal habits such as smoking.

The regional variation in rates could not be explained by geographical differences in the age, sex, and occupational distribution of the working population. The relatively small numbers reported from Yorkshire and Humberside, the East Midlands, and South East England were consistent with the areas of the country with fewer cooperating chest clinics, and the relatively large numbers reported from the West Midlands, the North and Scotland were probably due to more complete reporting.

Cases of occupational lung disease reported to SWORD are the "tip of an iceberg". To be
Table $V$ Incidence of occupational asthma in relation to administrative region

\begin{tabular}{|c|c|c|c|c|c|c|}
\hline Region & Cases & Rate $/ \mathrm{mil} / \mathrm{y}$ & & $(95 \%(C I)$ & $\begin{array}{l}\text { Standardised } \\
\text { rate ratio }\end{array}$ & $(95 \% C I)$ \\
\hline $\begin{array}{l}\text { North - Tyne and Wear } \\
\quad \text { - Remainder }\end{array}$ & $\begin{array}{l}28 \\
62\end{array}$ & $\begin{array}{l}31 \\
37\end{array}$ & 34 & $(28,43)$ & 1.58 & $(1 \cdot 28,1.95)$ \\
\hline $\begin{aligned} & \text { Yorkshire \& Humberside } \text { South Yorkshire } \\
& \text { - West Yorkshire } \\
& \text { - Remainder }\end{aligned}$ & $\begin{array}{l}20 \\
17 \\
29\end{array}$ & $\begin{array}{r}19 \\
9 \\
20\end{array}$ & 15 & $(12,19)$ & 0.67 & $(0.52,0.86)$ \\
\hline East Midlands-All & 51 & 13 & 13 & $(10,18)$ & 0.60 & $(0 \cdot 46,0 \cdot 79)$ \\
\hline East Anglia - All & 40 & 20 & 20 & $(14,27)$ & $1 \cdot 05$ & $(0.77,1.43)$ \\
\hline $\begin{array}{c}\text { South East-Greater London } \\
\text { - Remainder }\end{array}$ & $\begin{array}{r}62 \\
151\end{array}$ & $\begin{array}{l}10 \\
14\end{array}$ & 13 & $(11,14)$ & 0.73 & $(0.63,0.84)$ \\
\hline South West-All & 83 & 19 & 19 & $(15,23)$ & 0.97 & $(0 \cdot 78,1 \cdot 21)$ \\
\hline $\begin{array}{c}\text { West Midlands - Metropolitan county } \\
\text { - Remainder }\end{array}$ & $\begin{array}{r}152 \\
69\end{array}$ & $\begin{array}{l}65 \\
27\end{array}$ & 45 & $(39,51)$ & $1 \cdot 76$ & $(1.53,2.02)$ \\
\hline $\begin{array}{c}\text { North West - Greater Manchester } \\
\text { - Merseyside } \\
\text { - Remainder }\end{array}$ & $\begin{array}{l}30 \\
29 \\
64\end{array}$ & $\begin{array}{l}13 \\
25 \\
30\end{array}$ & 22 & $(18,26)$ & $1 \cdot 04$ & $(0.87,1 \cdot 24)$ \\
\hline Wales-All & 54 & 22 & 22 & $(17,29)$ & $0 \cdot 85$ & $(0.63,1 \cdot 15)$ \\
\hline $\begin{array}{c}\text { Scotland - Central Clydeside Conurbation } \\
\text { - Remainder }\end{array}$ & $\begin{array}{l}35 \\
90\end{array}$ & $\begin{array}{l}26 \\
29\end{array}$ & 28 & $(23,33)$ & $1 \cdot 32$ & $(1.09,1.59)$ \\
\hline Northern Ireland - All & 19 & 16 & 16 & $(10,25)$ & $0 \cdot 86$ & $(0.55,1.35)$ \\
\hline All UK & 1085 & 20 & & $(19,22)$ & & \\
\hline
\end{tabular}


included in our statistics a patient must be seen by a participating physician who must not only recognise the occupational aetiology but remember to report the case. Many patients with respiratory symptoms do not seek medical advice, some for fear of losing their job. Others are seen by a general practitioner, but are not referred to a specialist. Those reported to SWORD represent only a fraction of the actual number of new cases of occupational asthma in the United Kingdom, and therefore all the incidence rates in this analysis are underestimated.

Although rates for the West Midlands Metropolitan County were no doubt underestimated for the reasons mentioned, the presence of a regional surveillance scheme ${ }^{8}$ which increased local awareness of occupational asthma was probably responsible for the relatively high reported incidence from the region. If the same occupational rates had been achieved for the whole of the UK, the number of new cases seen by chest and occupational physicians during the two years would have been nearly three times that reported. This rough calculation gives only some indication of the degree of underascertainment, but it is the best estimate available.

I gratefully acknowledge contributions to this project by all participating physicians and in particular the members of our advisory panels: Drs P S Burge, I I Coutts, A G Davison, P G Harries, D J Hendrick, J Osman, M G Pearson, C A C Pickering, and J E Stark, and Professors P C Elmes, A J Newman Taylor, and A Seaton. Professor Corbett McDonald supervised the project and much help has been given by other unit staff (Linda Crombie, Elizabeth Paul, and Vivien Taylor).

The SWORD project is supported by a grant from the Health and Safety Executive.

1 Health and Safety Executive. Health and safety statistics 1989-90. Employment Gazette 1992; 100: no 9 (Occasional Suppl no 3): $75-94$.
2 Meredith SK, Taylor VM, McDonald JC. Occupational respiratory disease in the United Kingdom 1989: a report to respiratory disease in the British Thoracic Society and the Society of Occupational Medicine by the SWORD project group. Br $\mathcal{F}$ Occupational Medicine by

Ind Med 1991; 48: 292-8.
Thoracic medical services in the United Kingdom. London: The British Thoracic Society, 1988

4 Office of Population Censuses and Surveys. Classification of occupations 1980. London: HMSO, 1980

5 Department of Health and Social Security. Social Security Act 1975-occupational asthma. London: HMSO, 1981 Cmnd 8121

6 Department of Health and Social Security. Social Security Act 1975-occupational asthma. London: HMSO, $1986 \mathrm{Cmnd}$ 9717 .

7 Department of Social Security Social Security Act 1975 occupational asthma. London: HMSO, $1990 \mathrm{Cmnd} 1244$.

8 Gannon PFG, Burge PS. A preliminary report of a surveillance scheme of occupational asthma in the West Midlands. Br F Ind Med 1991; 48: 579-82.

9 Burge SP. Occupational asthma in electronics workers caused by colophony fumes: follow-up of affected workers. Thorax 1982; 37: 348-53.

10 Lozewicz BK, Assoufi BK, Hawkins R, Newman Taylor AJ Outcome of asthma induced by isocyanates. $\mathrm{Br} \mathcal{F}$ Dis Chest 1987; 81: 14-22.

11 Chan-Yeung M, MacLean L, and Paggiaro PL. Follow-up study of 232 patients with occupational asthma caused by western red cedar (Thuja plicata). 7 Allerg. Clin Immunol 1987; 79: 793-6.

12 Meredith SK, McDonald JC. Occupational asthma in chemical, pharmaceutical and plastics processors and manufacturers in the United Kingdom, 1989-1990. Inhaled particles VII, Ann Occup $H_{y} 1993$ (in press).

13 Keskinen H, Alanko K, Saarinen L. Occupational asthma in Finland. Clinical Allergy 1978; 8: 569-79.

14 Cockcroft A, Edwards J, McCarthy P, Andersson N. Allergy in laboratory animal workers. Lancet $1981 ;$ i; 827-30.

15 Venables KM, Tee RD, Hawkins ER et al Laboratory anima allergy in a pharmaceutical company. Br fInd Med 1988; 45 : 660-6.

16 Burge PS, Edge G, Hawkins R, White V, Newman Taylor AJ. Occupational asthma in a factory making flux-cored solder containing colophony. Thorax 1981;36: 828-34.

17 Musk AW, Venables KM, Crook B, et al. Respiratory symptoms, lung function, and sensitization to flour in a symptoms, lung function, and sensitization to

18 Slovak AJM. Occupational asthma caused by a plastics blowing agent, azodicarbonamide. Thorax 1981; 36: 906-9.

19 Seguin P, Allard A, Cartier A, Malo JM. Prevalence of occupational asthma in spray painters exposed to several types of isocyanates, including polymethylene polyphenylisocyanate. F Occ Med 1987; 29: 340-4.

20 Soyseth V, Kongerud J. Prevalence of respiratory disorders among potroom workers in relation to exposure to fluoride. Br f Ind Med 1992; 49: 125-30.

21 Kilburn $\mathrm{KH}$, Warshaw RH. Irregular opacities in the lung, occupational asthma, and airways dysfunction in occupational asthma, and airways dysfunction in

22 Johnson A, Chan-Yeung M, Maclean L et al. Respiratory abnormalities among workers in an iron and steel foundry. Br f Ind Med 1985; 42: 94-100. 